\title{
Enhancing Civilisational Dialogue between Malaysia and the European Union
}

\author{
Christoph Marcinkowski*
}

Cooperation between the European Union (EU) and Malaysia started with the 1980 European Commission-ASEAN Agreement which has made it possible for Malaysia to benefit from a number of ASEAN and Asia-wide cooperation programmes. The EU Delegation to Malaysia was opened in 2003 and since then dialogue, policy interaction and cooperation with both federal and state authorities, the Malaysian and EU business community as well as the civil society has increased progressively. Moreover, Malaysia is also the EU's second most important trading partner in ASEAN. No bilateral preferential trade arrangements exist between Malaysia and the EU, but under the new Generalised System of Preferences (GSP), in force since January 2006, the share of Malaysia's merchandise exports to the EU eligible for preferential treatment rose from 16 per cent to 81 per cent. Over 70 per cent of Malaysia's exports to the EU now enter duty-free. Malaysia records a trade surplus with most EU Member States.

To the mind of the writer, however, EU-Malaysian relations are all too often reduced to facets that are related to economics and trade alone. Perhaps, EU-Malaysian relations are all too often focusing on facets that are related to economics, trade, technology, or cooperation in the vocational or academic sectors - in other words, a scenario where Malaysian students are trained in Europe and by Europeans, where European goods can be sold to Malaysians who are on the receiving end - an end where the 'big money' is supposedly to be made quickly. Such a mechanism, however, is surely favouring only one side. But what about civilisational dialogue within this setting, a dialogue which would well produce positive long-term effects for all parties involved?

In order to counter this trend, the extension of cultural cooperation between the EU and Malaysia - a multicultural country that is also one of the leading nations of the Muslim world - could well open up new avenues of cooperation and understanding. Issues pertaining to the environment, human rights, security, migration, and higher education, for instance, are currently gaining in importance.

\section{Possibilities and Challenges}

With over 500 million citizens, the EU combined generated an estimated 28 per cent share (US\$16.5 trillion) of the nominal and about 21 per cent (US\$14.8 trillion) of

* Dr Christoph Marcinkowski is Principal Research Fellow at IAIS Malaysia. From 2007 to 2008 , he was Senior Research Fellow at the Asia-Europe Institute (AEI), University of Malaya, Kuala Lumpur. 
the PPP gross world product in 2009. ${ }^{1}$ The EU has developed a single market through a standardised system of laws, which apply in all member states, and ensures the free movement of people, goods, services and capital, including the abolition of passport controls by the Schengen Agreement. The EU also maintains common policies on trade, agriculture, fisheries, and regional development. Moreover, 16 member states have adopted a common currency - the euro, currently somewhat under pressure - to constitute what is commonly known as the 'eurozone'. As a legal entity the EU is able to conclude treaties with countries and enact legislation in justice and internal affairs. It has devised the Common Foreign and Security Policy, thus developing a limited role in European defence and foreign policy. Permanent diplomatic missions of the EU are established around the world - including Malaysia. The EU operates through a hybrid system of 'supranationalism' and 'intergovernmentalism': in certain areas, decisions are taken by independent supranational institutions, while in others they are made through negotiation between member states.

The EU is an economic and political union of 27 member states with different interests and constitutional settings. However, although there already exist several institutions which focus explicitly on Malaysian-EU relations - among them the Malaysia Europe Forum which quite recently, in March 2010, staged its 'Malaysia Europe Forum Spring Dialogue' in Munich, Germany - there is much more to do to make true Malaysian-European dialogue a reality. Most of these institutions happen to function as mere platforms for bringing together business people from both regions. However, what we are talking about here is intercultural dialogue for its own sake whereby other, certainly legitimate, agendas, would remain in the background. Recently, Professor Corrado Letta - a colleague of mine during my time at the University of Malaya's Asia-Europe Institute (AEI) - wrote Malaysia-Europe: Strategic Partnerships for the Pacific Century, published by Malaysia's Ministry of Foreign Affairs, a book which aims at critically examining Malaysia's diplomacy and foreign relations vis-à-vis the EU and how this affects both economies. However, in spite of this laudable effort toward moving beyond purely economic issues, there is, alas, not much reference to intercultural dialogue in it.

In order to address this serious issue and to fill in this gap for the first time, I have conceived the book Malaysia and the European Union: A Partnership for the 21st Century, which will be edited by Professor Letta in cooperation with Professor Ruhanas Harun (National Defence University of Malaysia) and Associate Professor Dr Constance Chevallier-Govers (University of Grenoble, France) and which will have a foreword by HE Vincent Piket, the Ambassador and Head of the EU Delegation to Malaysia. Malaysia and the European Union - forthcoming at a major European publishing house in 2011 - features essays by senior Malaysian and European practitioners and scholars as to the current state of relations between Malaysia and the European Union in core issues that would 
also include perspectives of cooperation in the fields of bilateral and multilateral relations, economics, finance, trade, the environment, higher education and academic cooperation, culture, gender, and intercivilisational dialogue, as well as human rights, security and international politics.

\section{Moving Beyond: Some Recommendations}

However, Malaysian-EU relations - and their extension beyond the fields of economics and trade - could also serve a wider purpose, a purpose that would contribute positively toward improving the rather strained relations between what are usually known (and rather clumsily subsumed) as 'the West' and 'the Islamic world', as Malaysia has always understood its own role as a bridge between those two major world civilisations.

Relations between Europe and the world of Islam could be improved through the extension of cultural cooperation between the EU and Malaysia, a multicultural country that is, nevertheless, also one of the leading nations of the Muslim world, which could play a vital part. Events, such as the 'Danish cartoon' issue, the military involvement of several EU member states in Afghanistan and other parts of the Muslim world or the hotly disputed issue of Turkey's bid for full membership in the EU are only some of the key indicators of the presently rather challenging state of affairs of European-Muslim relations. Moreover, in the last two decades or so, Muslims in Europe have managed to establish religious communities and to assert their identity in a more visible, public and - to some degree - more controversial manner.

In May 2010, IAIS Malaysia and the Embassy of the Federal Republic of Germany in Kuala Lumpur took a step in the right direction by jointly staging "The First International Seminar on Germany and Islamic Culture", a highly successful two-day event - partly organised by myself - which was also well received by many of the diplomatic representations accredited to Malaysia. Subsequently, several embassies of European countries have approached IAIS Malaysia, expressing their interest in jointly organising similar events.

There are thus several positive outcomes and suggestions for future cooperation for which the EU-Malaysian story could only be a beginning:

- Regular events, staged jointly with European embassies and hosted by IAIS Malaysia, that would enhance further the current status of the Institute as the one-stop place in Malaysia for intercivilisational dialogue between Western and Muslim nations, should be envisaged.

- Such events should also be planned in cooperation with other Western nations that have a considerable involvement with the Islamic world - at the forefront 
of those would be the United States which so far has kept a rather low profile in this regard, in spite of its Obama administration which is usually seen as somewhat more open to dialogue.

- The embassies of the nations of the Organisation of the Islamic Conference (OIC) accredited to Malaysia could also be approached in this project.

- By approaching both Western and Muslim nations in this dialogue project, it could become clear to all involved that neither of them constitutes a monolithic bloc, a realisation which could enhance further the building of trust between them.

In closing then, although I am aware that these are just ideas on the basis of 'brainstorming', they could, nevertheless, well become the basis of further, more concrete planning, as IAIS Malaysia has in the course of its first two years of existence established itself as an important forum of intercivilisational dialogue in the Southeast Asian region and beyond.

\section{Note}

1. World Economic Outlook Database, April 2010, International Monetary Fund, a vailable online at http://www.imf.org/external/pubs/ft/weo/2010/01/weodata/weorept.aspx?sy=2005\&ey=2009\&scs $\mathrm{m}=1 \& \mathrm{ssd}=1 \&$ sort $=$ country $\& \mathrm{ds}=. \& \mathrm{br}=1 \& \mathrm{c}=001 \% 2 \mathrm{C} 998 \& \mathrm{~s}=\mathrm{NGDP}$ RPCH $\% 2 \mathrm{CNGDPD} \% 2 \mathrm{CPP}$ PGDP\%2CPPPPC\%2CPPPSH\&grp=1\&a=1\&pr.x=36\&pr.y=15 (accessed on 25 June 2010). 